\title{
EARLY OUTCOME OF ADULT CARDIAL SURGERY IN LOW VOLUME COMMUNITY HOSPITAL EXPERIENCES OF YOUNG SURGEON FROM DEVELOPING COUNTRY
}

\author{
Yan Efrata Sembiring \\ Departement of Thoracic and Cardiovascular Surgery, Faculty of Medicine, Dr Soetomo Hospital, Surabaya
}

\begin{abstract}
ABSTRAK
Setelah menyelesaikan pelatihan, setiap ahli bedah jantung pemula ingin memulai karir secepat yang mereka bisa. Kami menjelaskan hasil awal dari operasi yang dilakukan oleh ahli bedah jantung pemula memiliki volume rendah di rumah sakit komunitas di Surabaya - Indonesia dalam periode Desember 2010 - Desember 2013. Sebuah studi retrospektif dari 133 kasus jantung selama Desember 2010 - Desember 2013 di Divisi Bedah Toraks, Jantung dan Pembuluh Darah, RSUD Dr Soetomo Surabaya menyediakan data yang komprehensif mengenai prosedur bedah jantung yang dikumpulkan dan dianalisis. Dalam 3 tahun terakhir, jumlah total penyakit jantung dewasa yang menjalani operasi sebanyak 133 kasus. Prosedur yang terlibat CABG (85 kasus, 63,91\%); prosedur valve (7 kasus, 5,26\%); dan prosedur lain (6 kasus, 4,51\%). Semua kasus dilakukan oleh ahli bedah pemula. Tiga puluh hari pertama, 3 pasien menderita luka infeksi, 7 pasien dioperasi ulang karena perdarahan mediastinum dan tamponade jantung. Tingkat kematian sebesar 1,5\%. Simpulan, mentoring yang baik dari dokter bedah senior dan pelatihan yang baik memberikan hasil yang baik pula pada dokter bedah pemula di volume rendah rumah sakit komunitas. (FMI 2016;52:136-139)
\end{abstract}

Kata kunci: mentoring dokter bedah, ahli bedah jantung pemula, luka infeksi, perdarahan mediastinum, tamponade jantung

\begin{abstract}
After finishing training, every young cardiac surgeon wants to start a good carrier as fast as they can. We describe the early outcome of adult cardiac surgery that have been done by a young in low volume community hospital in Surabaya - Indonesia within periods December 2010 - December 2013. A retrospective study of 133 adult cardiac cases during December 2010 - December 2013 at Division of Thoracic, Cardiac and Vascular Surgery Dr. Soetomo Hospital Surabaya provides a comprehensive data concerning adult cardiac procedures which collected and analyzed. In last 3 years, the total number of adult cardiac disease which is undergone a surgery was 133 cases. The procedures were involved CABG (85 cases, 63.91\%); valve procedures (7 cases, 5.26\%); and others procedures (6 cases, $4.51 \%$ ). All cases were done by a young surgeon. Thirty day early follow up, there were 3 patients suffered from wound infection, 7 patients undergone re-do procedures due to mediastinal bleeding and cardiac tamponade. Mortality rate was $1.5 \%$. The conclusion, good mentoring from senior surgeon and good training give a good result of adult surgery done by a young surgeon in low volume community hospital. (FMI 2016;52:136-139)
\end{abstract}

Keywords: mentoring from senior surgeon, young cardiac surgeon, infection wound, mediastinal bleeding, cardiac tamponade

Correspondence: Yan Efrata Sembiring, Departement of Thoracic and Cardiovascular Surgery, Faculty of Medicine, Dr Soetomo Hospital, Surabaya. Phone: 081357309384.e-mail: yanefratas@yahoo.com

\section{INTRODUCTION}

The necessity to develop cardiac surgery field in developing country is challenging due to many reasons. It is because cardiac surgery requires teamwork that consists of not only a surgeon himself but also the cardiovascular anesthesist, cardiologist, perfusionist, well-trained nurses in instrumentation during operative procedures and post-operative care after cardiac surgery in intensive care room (Mascio et al 2011, Grover et al 2009). Cardiac surgery is the 'youngest' branch of surgery born in Indonesia comparing to the others divisions of surgery that formerly existed in Indonesian medical field. It impacts the development of cardiac surgery field in Indonesia. There are many aspects influencing the development of cardiac surgery, not only the facilities provided but also the availability of skillful surgeons and number of cases.

The lack of cases in developing country is not tribute to few number of disease existing. It rather refers to the diagnostic approach to define the disease itself. It can be depicted as "iceberg phenomenon". It is as an exceptional problem for cardiac surgeon in order to enhance their skill by doing operation as frequently as possible (Karamlou et al 2008). Training the foreign cardiac surgeon by following fellowship to developed country, sometimes, is not always easy to implement, because of preoccupation with their own daily business. Training of a complete team of cardiac surgery (cardiac surgeon, nurses, anesthesiologist, intensivist, perfusionist) is even more cumbersome, complex and more expensive and is 
often impossible without an established vision of the future that is adapted to local needs. The alternative way is transmitting knowledge within developing country itself by making regular and frequent visits to a selected center and performing surgery with the aid of local specialist program. This alternative manner of training has the further advantage of giving immediate highquality care to the local population (Ghosh 2005). Hospital that has low loaded cases, can also provide the freshly graduated cardiac surgeon sufficient experience to improve their skill by good training from senior (Pezzella 2001).

\section{MATERIALS AND METHODS}

We performed research to obtain all cases undergone cardiac surgery as well as the types of procedures and evaluating its outcome within 3 year period of time that had been done by cardiac surgeon in Division of Thoracic, Cardiac, and Vascular Surgery, Dr. Soetomo General Hospital Surabaya - Indonesia. We collected all data retrospectively from medical record. All collected data was processed descriptively.

\section{RESULT}

We obtained 133 patients $(n=133)$ undergone cardiac surgery from December 2010 - December 2013. The majority of cardiac surgery procedure done is Coronary Artery Bypass Grafting. Otherwise, the least number of procedure done is atrial septal defect closure and foreign body on the right ventricle (penetrating cardiac trauma due to gunshot wound). Data was analyzed on SPSS version 15.0. Quantitative variables e.g., age, weight, height, body mass index (BMI), body surface area (BSA), cardiopulmonary bypass time, cross clamp time, post-operative blood loss (chest, pericardial, and substernal drainage), ICU stay, ventilation duration, duration of inotropes and the hospital stay were expressed as mean and standard deviation (SD).
Frequency and percentages were used to describe categorical variables like gender, type of disease and surgery. Patient characteristics, morbidity and mortality were described.

\section{Patient characteristics}

The mean age was 35.67 years old ( $\mathrm{SD} \pm 10.8)$, mean weight was $50.48 \mathrm{~kg}(\mathrm{SD} \pm 15.46)$, mean height was $153.57 \mathrm{~cm}(\mathrm{SD} \pm 19.69)$, mean BMI was $20.86 \mathrm{~kg} / \mathrm{m} 2$ $(\mathrm{SD} \pm 38.78)$, and $\mathrm{BSA}$ was $1.376 \mathrm{~m} 2(\mathrm{SD} \pm 1.02)$. The gender distribution consisted of $95(71.4 \%)$ male and 38 $(28.6 \%)$ female.

Table 1. Patient characteristics

\begin{tabular}{lccc}
\hline $\begin{array}{c}\text { Characteristics of } \\
\text { Patients }\end{array}$ & Mean & Median & $\begin{array}{c}\text { Standard } \\
\text { Deviation }\end{array}$ \\
\hline Age (years old) & 35.67 & 33.48 & 10.8 \\
Weight $(\mathrm{kg})$ & 50.48 & 51.56 & 15.48 \\
Height $(\mathrm{cm})$ & 153.57 & 152.67 & 38.78 \\
BMI $(\mathrm{kg} / \mathrm{m} 2)$ & 20.86 & 19.98 & 38.78 \\
BSA $(\mathrm{m} 2)$ & 1.376 & 1.298 & 1.02 \\
\hline Gender & \multicolumn{3}{c}{ Male :95 (71.4\%) } \\
& \multicolumn{3}{c}{ Female : $38(28.6 \%)$} \\
\hline
\end{tabular}

\section{Diagnostic spectrum}

Patients consisted of 85 (63.9\%) coronary artery disease with three vessels disease (CAD 3VD), 10 (7.5\%) severe mitral stenosis with severe tricuspid regurgitation, $8(6.0 \%)$ severe mitral regurgitation with mild tricuspid regurgitation, $8(6.0 \%)$ severe mitral regurgitation with severe tricuspid regurgitation, 7 $(5.2 \%)$ coronary artery disease with three vessels disease with severe mitral regurgitation, $6(4.5 \%)$ severe mitral regurgitation with moderate aortic stenosis, 5 (3.7\%) atrial septal defect, $2(1.5 \%)$ severe mitral stenosis with mild tricuspid regurgitation, $1(0.7 \%)$ mild mitral stenosis with severe aortic regurgitation, and 1 $(0.7 \%)$ foreign body on the right ventricle due to penetrating cardiac trauma (gunshot wound).

Table 2. Diagnostic spectrums

\begin{tabular}{lll}
\hline \multicolumn{1}{c}{ Diagnosis } & $\mathrm{n}$ & \multicolumn{1}{c}{$\%$} \\
\hline Coronary artery disease with three vessels disease (CAD 3VD) & 85 & 63.9 \\
Severe mitral stenosis with severe tricuspid regurgitation & 10 & 7.5 \\
Severe mitral regurgitation with mild tricuspid regurgitation & 8 & 6.0 \\
Severe mitral regurgitation with severe tricuspid regurgitation & 8 & 6.0 \\
Coronary artery disease with three vessels disease with severe mitral regurgitation & 7 & 5.2 \\
Severe mitral regurgitation with moderate aortic stenosis & 6 & 4.5 \\
Atrial septal defect & 5 & 3.7 \\
Severe mitral stenosis with mild tricuspid regurgitation & 2 & 1.5 \\
Mild mitral stenosis with severe aortic regurgitation & 1 & 0.7 \\
Foreign body on the right ventricle due to penetrating cardiac trauma (gunshot wound) & 1 & 0.7 \\
\hline
\end{tabular}




\section{Surgical procedures}

Consequently, 85 (63.9) patients underwent CABG, that consisted of $40(30.0 \%)$ three grafting, $35(26.3 \%)$ four grafting, and $10(7.5 \%)$ five grafting. $35(26.3 \%)$ valve procedures consisted of $18(13.5 \%)$ mitral valve replacement with tricuspid valve repair, $10(7.5 \%)$ mitral valve replacement, 7 (5.3\%) mitral valve replacement and aortic valve replacement. Seven (5.3\%) CABG with mitral valve replacement. Five (3.8\%) ASD closure, consist of $1(0.7 \%)$ primary closure and the remaining $4(3.4 \%)$ closure by using patch (either goretex/dacron or pericardial patch). One $(0.7 \%)$ foreign body extraction with right ventricular repair.

\section{Outcome}

The main outcome variables analyzed were mean cardiopulmonary bypass time was 65.26 minutes $(\mathrm{SD} \pm 30.4)$, mean cross clamp time was 44.7 minutes ( $\mathrm{SD} \pm 27.04$ ), mean ICU stay was 24.22 hours ( $\mathrm{SD} \pm$ 12.64), mean ventilation duration was 4.8 hours
( $\mathrm{SD} \pm 6.8$ ), the mean duration of inotropes was 16.11 hours ( $\mathrm{SD} \pm 19.28)$, the mean chest drainage per 24 hours was $506 \mathrm{ml}(\mathrm{SD} \pm 526.27)$ and the mean hospital stay was 7.06 days $(\mathrm{SD} \pm 3.5)$. In the post operative complications, 24 hour period of time $7(5.2 \%)$ undergone re-do operation due to mediastinal bleeding and cardiac tamponade and after thirty day follow-up, 3 $(2.3 \%)$ suffered wound infection. Mortality was in 2 $(1.5 \%)$ due to low cardiac output syndrome and multiple organ dysfunction syndrome et causa cardiopulmonary bypass complication, each of both 1 (0.7) case.

\section{DISCUSSION}

The most frequent case obtained from all collected data is coronary artery disease about $63.3 \%$ of cases. Consequently the most common procedures done is coronary artery bypass graft about $63.9 \%$. Severe mitral valve condition either stenosis or regurgitation is the second most common $(7.5 \%$ for mitral stenosis and $6.0 \%$ for mitral regurgitation respectively).

Table 3. Surgical Procedures

\begin{tabular}{clcl}
\hline \multicolumn{1}{c}{ Surgical Procedures } & $\mathrm{n}$ & $\%$ \\
\hline CABG & & 85 & 63.9 \\
- & CABG with three grafts & 40 & 30.0 \\
- & CABG with four grafts & 35 & 26.3 \\
- & CABG with five grafts & 10 & 7.5 \\
Valve Procedures & 35 & 26.3 \\
- $\quad$ Mitral valve replacement with tricuspid valve repair & 18 & 13.5 \\
- & Mitral valve replacement & 10 & 7.5 \\
- & Mitral valve replacement and aortic valve replacement & 7 & 5.3 \\
CABG with mitral valve replacement & 7 & 5.3 \\
ASD closure & 5 & 3.8 \\
- $\quad$ Primary closure & 1 & 0.7 \\
- $\quad$ Patch (goretex/dacron or patch) & 4 & 3.4 \\
Foreign body extraction with right ventricular repair & 1 & 0.7 \\
\hline
\end{tabular}

Table 4. Outcome, complication and mortality

\begin{tabular}{lcc}
\hline \multicolumn{1}{c}{ Outcome } & Mean & SD \\
\hline Cardiopulmonary bypass time (minutes) & 65.26 & 30.4 \\
Cross clamp time (minutes) & 44.7 & 27.04 \\
ICU stay (days) & 24.22 & 12.64 \\
Ventilation duration (hours) & 4.8 & 6.8 \\
Duration of inotropes (hours) & 16.11 & 19.28 \\
Chest drainage per 24 hours (ml) & 506 & 526.27 \\
Hospital stay (days) $\quad$ Complication and Mortality & 7.06 & 3.5 \\
Post operative complication & $\mathrm{n}$ & $\%$ \\
$-\quad$ Re-do operation (mediastinal bleeding and cardiac tamponade) & 7 & 5.2 \\
$-\quad$ Wound infection & 3 & 2.3 \\
Mortality rate & 2 & 1.5 \\
\hline$-\quad$ Low cardiac output syndrome & 1 & 0.7 \\
\hline$\quad$ Multiple organ dysfunction syndrome due to cardiopulmonary & 1 & 0.7 \\
\hline
\end{tabular}


Valve Procedure itself account as high as $26.3 \%$ which consist of Mitral Valve Replacement (7.5\%) and Mitral valve replacement with tricuspid valve repair (13.5\%). Subsequently, Condition require Coronary Artery bypass graft concomitant with mitral valve replacement are $5.3 \%$. In Such Condition mentoring from senior surgeon is require due to level of difficulty's procedures. Post Operative complication consist of two condition which is Re-do Operation due to mediastinal bleeding and cardiac tamponade (5.2\%) and wound infection $(2.3 \%)$. Mortality rate as high as $1.5 \%$ consist of Low Cardiac Output syndrome $(0.7 \%)$ and Multiple Organ dysfunction syndrome due to cardiopulmonary bypass complication $(0.7 \%)$. The complication and mortality rate are relatively low comparing to the number of patient involved in data. Number of cases are mandatory to achieve sufficient skill and standard of surgical service. Mentoring from senior cardiac surgeon also have fundamental role to shape skillfull and high standard of surgical service. Especially in patient with advance cardiac pathology or require complex procedure (i.e MVR with CABG ).

\section{CONCLUSION}

As explained from the result, young surgeon can do adult cardiac surgery procedures in relatively low complication and mortality rate. The low loaded case in general hospital should not be an obstacle for young cardiac surgeon to improve their skill. Another aspect that importantly influences, that is, good mentoring and good training from senior cardiac surgeon.

\section{REFERENCES}

Ghosh P (2005). Setting up an open heart surgical program in a developing country. Asian Cardiovasc Thorac Ann 13, 299-301

Grover A, Gorman K, Dall TM, Jonas R, Lytle B, Shemin R, Wood D, Kron I (2009). Shortage of cardiothoracic surgeons is likely by 2020 . Circulation $120,488-494$

Karamlou T, Diggs BS, Person T, Ungerleider RM, Welke KF (2008). National practise patterns for management of adult congenital heart disease. Circulation 118, 2345-2352

Mascio CE, Pasquali SK, Jacobs JP, Jacobs ML, Austin EH (2011). Outcomes in adult congenital heart surgery: analysis of the Society of Thoracic Surgeons (STS) Database. J Thorac Cardiovasc Surg 142, 10901097

Pezzella AT (2001). Progress in international cardiac surgery: emerging strategies. Ann Thorac Surg 71, 407-408 